\title{
A Study of Interactional Metadiscourse Markers and Gender in the Defense Seminars of Persian Speakers
}

\author{
Raha Zareifard \\ University of Isfahan, Iran. \\ E-mail: rahazareifard@yahoo.com \\ Batool Alinezhad \\ University of Isfahan, Iran. \\ E-mail:batool_alinezhad@yahoo.com
}

Doi:10.5901/jesr.2014.v4n1p231

\begin{abstract}
This paper aims to analyze the relation between a linguistic behavior, namely interactional metasdicourse, and a non-linguistic variable, namely, gender in thesis defenses of Persian speakers. Based on the model of community of practice, a qualitative and quantitative analysis of the metadiscourse markers employed by male and female candidates in thesis defenses have been carried out. The data include eighteen thesis defenses of nine males and nine females in humanities and social sciences. The quantitative analysis represents a statistically significant difference in the use of interactional metadiscourse markers by male and female candidates. The qualitative analysis, however, indicates the existence of some similarities among these two social groups in using the types of metadiscourse markers in the defense seminars of Persian speakers.
\end{abstract}

Keywords: Gender, Community of practice, Thesis defenses, Interactional metadiscourse markers.

\section{Introduction}

The interpersonal nature of academic communication has been stressed in the last few decades (e.g. Rowley-Jolivet and Carter-Thomas, 2005). However, such studies are rather overlooked as far as Persian language is concerned, in particular in area of the spoken Persian. The current study, then, is focused on one of the unexplored subcategory of spoken language, namely thesis defenses (hereafter TDs). Iranian researchers have directed their attention toward the written academic discourse (see for example Abdi, 2009; Abdollahzadeh, 2007; Simin, 2004), the spoken academic discourse in Persian presents then itself as a new area for investigation.

Furthermore, the study of gender metadiscourse phenomenon has also been underexplored in Persian language. Ädel (2006: 198) emphasizes that gender of the writer could influence how much or what type of metadiscourse is used. This study then aims to redress the issue by dealing with this aspect of Persian linguistic behavior. The research addresses issues such as the extent in which similarities and differences can be found in the use of interactional metadiscourse markers by male and female candidates in thesis defenses. To this end, the papar adopts the model of community of practice suggested by Eckert and McConnell-Ginet (1992) with the aim of providing a more accurate interpretation of discourse interaction in contrast to other approaches (dominance and difference approaches).

\section{Theoretical Preliminaries}

There have been at least two approaches for the study of language and gender over the last few decades: dominance approach and difference approach. In the former approach (Lakoff, 1975), some pre-established characteristics such as speaking indirectly, rapport talk, and cooperation are attributed to women's talk. By contrast, characteristics such as speaking directly, report talk, and competitiveness are attributed to men's talk. In the latter approach, the differences between men's and women's talk are treated as a result of different subcultures and different ways of socialization. Recently, however, many scholars (e.g. Mills, 2003) in the area of language and gender, believe that types of practice is the most important factor which affects the interactions of interlocutors. They have employed the term "community of practice" for their study of language and gender. "Community of practice" has strong link with social constructionist 
approaches which concentrate on the dynamic construction of gender with other factors such as identity and face in interactions. Eckert and McConnell-Ginet (1992: 464) define a "community of practice" as:

An aggregate of people who come together around mutual engagement in an endeavor. Ways of doing things, ways of talking, beliefs, values, power relations- in short, practices - emerge in the course of this mutual endeavor. As a social construct, a "community of practice" is different from the traditional community, primarily because it is defined simultaneously by its membership and by the practice in which that membership engages.

This study will be then focused on the investigation of gender communication based on the model of "community of practice" to explore the metadiscourse markers employed by either gender. Metadiscourse has been defined as the cover term for the self-reflective expressions used to negotiate interactional meanings in a text, assisting the writer [or speaker] to express a viewpoint and engage with readers [or audience] as members of a particular community (Hyland, 2005: 37). Crismore (1984: 280) believes that the aim of metadiscourse is to direct rather than inform the readers [or audience]. Metadiscourse features have traditionally been divided into textual and interpersonal. However, Hyland (2004, 2005) and Hyland and Tse (2004: 157) propose a stronger interpersonal function for metadiscourse: "...all metadiscourse is interpersonal in that it takes account of the reader's [or audience's] knowledge, textual experiences and proposing needs".

Although the current study has benefited from a number of studies in area of metadiscourse (Vande Kopple, 1985; Crismore et al, 1993; Hyland, 1999, 2000, 2005), it mainly rests on the analysis of Hyland and Tse (2004). They adopt Thompson's (2001) description of interactive and interactional resources as two inter-related aspects of interaction. They divide metadiscourse into two categories: interactive metadiscourse and interactional metadiscourse. The focus of interactive metadiscourse centers on the content of the text and some resources such as transitions, frame markers, endophoric markers, evidentials and code glosses. While interactional resources focus on the participants of the interaction and seek to display the writer's [speaker's] persona and a tenor consistent with the norms of the disciplinary community. The following table illustrates these subcategories and their functions.

Table 1: Interactional Metadiscourse

\begin{tabular}{|c|c|c|}
\hline Category & Function & \multirow[t]{2}{*}{ Examples } \\
\hline Interactional metadiscourse & involve the reader[audience] in the argument & \\
\hline Hedges & $\begin{array}{l}\text { withhold writer's[speaker's] full commitment to roposition } \\
\text { [utterance meaning] }\end{array}$ & might / perhaps / possible / about \\
\hline Boosters & $\begin{array}{l}\text { emphasize force or writer's [speaker's] certainty in } \\
\text { proposition[utterance meaning] }\end{array}$ & in fact / definitely / it is clear that \\
\hline Attitude markers & $\begin{array}{l}\text { express writer's [speaker's] attitude to a proposition [utterance } \\
\text { meaning] }\end{array}$ & unfortunately / / agree / surprisingly \\
\hline Engagement markers & explicitly refer to or build relationship with reader [audience] & $\begin{array}{l}\text { consider / note that / you can see } \\
\text { that }\end{array}$ \\
\hline Self-mentions & explicit reference to author(s) [speaker(s)] & I/we/my/our \\
\hline
\end{tabular}

Sourse: Hyland \& Tse, 2004:169.

As it is mainly the interactional metadiscourse, that reveals the relationship between the speaker and the audience, the present study is then focused primarily on the gender linguistic behavior related to ways of employing interactional metadiscourse.

\section{Data and Method}

In order to carry out the description of gender-related interactional metadiscourse, the data were collected from a number of MA TDs in Shiraz University, July- August 2011 at the Humanities and Social Sciences Faculty. The time allocated to each candidate to defend his/her thesis was about thirty minutes. On the whole, eighteen defenses (nine by men and nine by women) were selected. All of them were tape-recorded. Next, these defenses were transcribed and were carefully read and examined for different features of interactional metadiscourse. Once it was determined that a given feature qualified as interactional metadiscourse, it was assigned to one of the subcategories. Next, each feature was carefully analyzed based on the context of situation to ensure that it actually functioned as an interactional metadiscourse marker and could be incorporated into the counts. The study was conducted to investigate the role of gender in relation to the quantity and quality of interactional metadiscourse in TDs. 


\section{Results}

Table (2) shows the frequency differences of interactional metadiscourse by male and female candidates. As the table shows, female candidates (FCs) tend to use more interactional metadiscourse in their defenses in comparison to male candidates (MCs). The figures in table (2) also illustrate that both MCs and FCs strongly emphasize their roles as the researchers and the audience as active participants in the negotiation of new scientific knowledge. These interactive roles are emphasized through the greater use of self-mentions and the use of engagement markers in their defenses. Although both groups, male and female, employ the same metadiscourse markers such as attitude markers, boosters, engagement markers, hedges and self-mentions, their frequency order is quite different. In other words, the frequency order of interactional metadiscourse markers in the male group is self-mentions, boosters, attitude markers, engagement markers and hedges, while they hold a different frequency order such as attitude markers, self-mentions, boosters, hedges, and engagement markers in the female group.

Table (2) provides the frequency order of each interactional metadiscourse marker in the two different groups under investigation.

Table 2: The frequency of interactional metadiscourse markers in TDs

\begin{tabular}{|l|c|c|c|c|}
\hline Types of Metadiscourse & $\begin{array}{c}\text { MC } \\
\text { (No of occurrence) }\end{array}$ & Total percentage & $\begin{array}{c}\text { FC } \\
\text { (No of occurrence) }\end{array}$ & Total percentage \\
\hline Hedges & 164 & 10.3 & 310 & 17.8 \\
\hline Boosters & 363 & 22.8 & 366 & 21 \\
\hline Attitude markers & 243 & 15.3 & 424 & 24.3 \\
\hline Engagement markers & 189 & 11.9 & 250 & 14.3 \\
\hline Self-mentions & 627 & 39.5 & 390 & 22.4 \\
\hline Total & 1586 & 100 & 1740 & 100 \\
\hline
\end{tabular}

To see if there was any statistically significant difference in the use of interactional metadiscourse by MCs and FCs, a chi-square test was run. Table (3) shows the summary of this chi-square.

Table 3: Results of chi-square test of MCs and FCs' use of interactional metadiscourse

\begin{tabular}{|l|c|c|c|}
\hline & value & df & Asymp. Sig. (2-sided) \\
\hline Pearson Chi-Square & $150.999 \mathrm{a}$ & 4 & .000 \\
Likelihood Ratio & 152.572 & 4 & .000 \\
Linear-by-Linear Association & 32.841 & 1 & .000 \\
N of Valid Cases & 3326 & & \\
\hline
\end{tabular}

As table (3) shows, the observed chi-square $(x 2=150.999)$ is significant at a level $(\alpha=0.05)$, which indicates that there is a significant difference between these two groups in their use of interactional metadiscourse. This is illustrated in Figure 1. There is a significant difference between the use of hedges, attitude markers, self-mentions and engagement markers in these two groups (Figure 1). Also, Figure (1) shows that both MCs and FCs strongly underscore their roles as researchers. This interactive role is emphasized through a greater use of self-mentions.

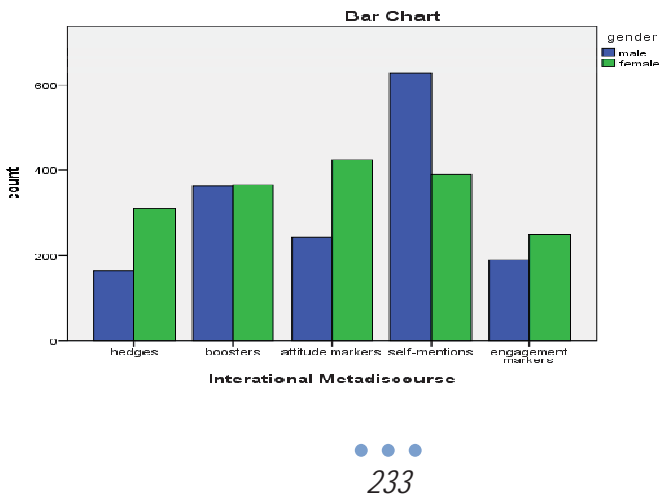




\section{Data Analysis}

\subsection{Hedges}

According to Hyland (1996: 261), in science, hedging is predominantly an element of persuasion, enabling claims to be expressed with precision, caution and humility and to meet audience expectations of accuracy and negotiation. As can be seen in Figure (1), women use hedges more than men. Also, as Table (3) shows, there is a significant difference in their manipulation. However, all candidates employed content-motivated and speaker-motivated hedges in a similar way. This can be illustrated by looking at 1(a) which belongs to an MC and 1(b) which belongs to an FC:

1 a)

$\begin{array}{lllllll}\text { agar mā } & \text { yek } & \text { kelidvāzhe-ye } & \text { khās } & \text { bekhāhim shāyad estelāhe } \\ \text { if } & \text { we } & \text { one } & \text { keyword-Ez }{ }^{1} & \text { special } & \text { want perhaps expression } \\ \text { mokhātereh } & \text { estelāh-e } & \text { monāsebi } & \text { bāshe } & & & \\ \text { risk expression-Ez } & \text { appropriate } & \text { be } & & \end{array}$

1 b)

"If we want a special keyword, perhaps risk would be an appropriate expression" (MC)

$\begin{array}{llllll}\text { aval in } & \text { ke } & \text { ghavānin tu-ye dāneshgāh mesl-e har } & \text { sāzemān-edige } \\ \text { first this } & \text { that } & \text { rules in-Ez } & \text { university like-Ez each institution-Ez other }\end{array}$

tāhododi enetāfnāpazire

to some extent fixed

"Firstly, rules in university are almost fixed like other institutions" (FC)

In 1(a) the MC uses a modal verb (bāshe) and an adverb (shāyad) and in 1(b) the FC uses an adverb (tāhododi) as content-motivated hedges to show how they understand, evaluate and respond to the utterance at hand (Hyland, 1996). Content-motivated hedges mitigate the relationship between what the speaker says about the world and what the world thought to be like (Hyland, 1996: 258). The candidates use this kind of hedges to present claims as accurately as possible which affect their evaluation in this community of practice.

The candidates also use speaker-motivated hedges. This point can be illustrated by looking at $2(a, b)$ below.

2 a)

$\begin{array}{llllllll}\text { in } & \text { tahghigh modaeiye ke } & \text { do } & \text { no' } & \text { avāmel } & \text { yeki } & \text { dākheli } & \text { va } \\ \text { this } & \text { research claimed that } & \text { two } & \text { kind } & \text { factors } & \text { one } & \text { internal and }\end{array}$

yeki khāreji monjar be

one external leads to

"This research claimed that two kinds of factors, internal and external, leads to..." (MC)

2 b)

$\begin{array}{lllllll}\text { tā hodudi mishe goft hattā mahdud shode be bāft-e ejtemāei } \\ \text { to } & \text { extent can say } & \text { even limited become to } & \text { context-Ezsocial }\end{array}$

"It can be said that even it is almost limited to social context" (FC)

In 2 (a), an MC have used 'abstract rhetor' (in tahghigh) and an FC have used passive construction (tā hodudi mishe goft) to avoid assuming direct personal responsibility for a claim and attribute claims to the data. As Chafe (1982) mentioned that traditionally the passive construction has been one of the principal means of achieving impersonality and distance in a text as it enables the removal of any explicit agency. Overall, by using hedges, the candidates (MCs and FCs) imply that the utterance is based on plausible reasoning rather than certain knowledge, indicating the degree of uncertainty involved (Hyland, 2005). Moreover, hedges in academic discourse reflect the critical importance of distinguishing a fact from an opinion (Hyland, 1998: 445). This behavior should not be viewed as a kind of uncertainty typical of women's character (Ochs, 1992).

\subsection{Boosters}

Both MCs and FCs tend to highlight the certainty they feel toward the proposition being made by the heavy use of boosters (Table 2). Examples $3(a, b)$ illustrates this tendency:

3 a)

\footnotetext{
${ }^{1}$ ezafe construction
} 
3 b)

\begin{tabular}{lllll} 
hoviyat-e melli & \multicolumn{2}{l}{ daghighan māhasale enghelabhāye } & san'ati va \\
identity-Eznational & exactly & result revolutions & industrial & and \\
makhsusan & zohur-e & dulatha-ye & meliye & \\
specially appearance-Ez & government-Ez & national
\end{tabular}

"National identity is exactly the result of industrial revolutions and specially the appearance of national government". (MC)

chenānke dar band-e panj in nokte kāmelan peydā hastesh
as in part-Ez five this issue completelyvisible is

"As in part five, this issue is completely obvious" (FC)

In $3(a, b)$, the MC and the FC use adverbs (daghighan, kāmelan) to express their confidence in what they are about to say (Hyland, 2005: 179).

\subsection{Attitude markers}

FCs tend to use attitude markers more frequently than MCs and the difference is statistically significant (Table 3). By using attitude markers, candidates try to interact more with their audience and to express a position and pull the audience into a conspiracy of agreement to the extent that it is often difficult to dispute these judgments (Hyland, 2005: 180). This point is illustrated in $4(a, b)$.

4 a)

$\begin{array}{llll}\text { khoshbakhtāneh } & \text { hame-ye meghyāsha mizān-e } & \text { ghābeleghabule } \\ \text { Fortunately } & \text { all-Ez scales amount-Ez } & \text { acceptable }\end{array}$

ro dāshtand

$\mathrm{Om}^{2} \quad$ had

"Fortunately, all of the scales had acceptable amount" (MC)

4 b)

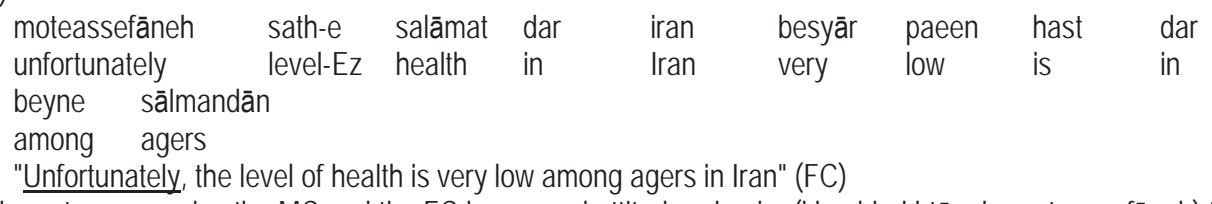

In these two examples the $\mathrm{MC}$ and the FC have used attitude adverbs (khoshbakhtāneh, moteassefāneh) to signal assumptions of shared attitudes and values. Sometimes, the candidates have used intensifiers (kheili and besyār) to convey their attitudes. The following two examples show this kind of manipulation:

5 a)

$\begin{array}{llllll}\text { albatteh yek matlab hast ke kneili jālebeh ke } \\ \text { ofcourse one } & \text { subject is } & \text { that } & \text { very } & \text { interesting which }\end{array}$

5 b)

"Of course, there is an issue, very interesting, which ..." (MC)

$\begin{array}{lllll}\text { ān } & \text { chizi } & \text { ke } & \text { besyār jālebeh ine } & \text { ke } \\ \text { that thing } & \text { that } & \text { very } & \text { interesting this } & \text { that }\end{array}$

"What is very interesting is that ..." (FC)

In $5(a, b)$, both candidates have employed the structure "intensifier + attitude adjective (jāleb)" to convey their attitudes and to persuade the audience (Hyland, 1998).

\subsection{Engagement Markers}

MCs do not use engagement markers as much as their female peers do (189 vs. 250). Nevertheless, they use the same strategies to engage with the audience. In a sense, they tend to use audience pronouns, personal asides, and appeals to shared knowledge, directives and questions. For instance, they use similar audience pronouns $(6 \mathrm{a}, \mathrm{b})$.

\footnotetext{
${ }^{2}$ object marker
} 
6 a)

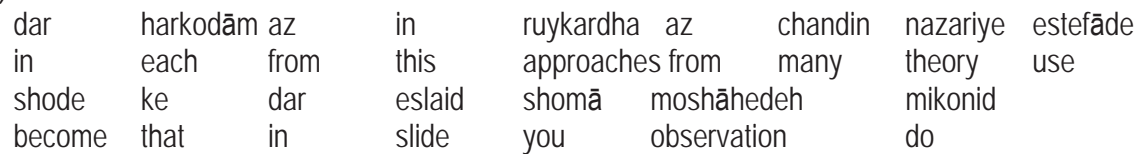

6 b)

"In these approaches, many theories were used which you observe in the slide" (MC)

$\begin{array}{llllllll}\text { shabake-ye } & \text { ejtemāei } & \text { ke } & \text { shomā } & \text { dar } & \text { javāni shekl midahid dar } \\ \text { network-Ez } & \text { social } & \text { that } & \text { you } & \text { in } & \text { youth form give in }\end{array}$

"Social network that you make in youth in ...." (FC)

Audience pronouns are perhaps the most explicit way that audience is brought into a discourse. It sends a clear signal of membership by constructing both the speaker and the audience as participants with similar understanding and goals (Hyland, 2005). As it can be observed in $6(a, b)$, both candidates have used the same audience pronoun (shomā) for engaging with the audience. The use of personal asides is also illustrated in $7(a, b)$ below.

7 a)

$\begin{array}{lllllll}\text { ke in } & \text { khodesh } & \text { mitune } & \text { mo'zal } & \text { bāshe barā-ye vazeiyat-e mā } \\ \text { that this } & \text { itself } & \text { can } & \text { problem be be be } & \text { be for-Ez situation-Ez we } \\ \text { albatte dar } & \text { āyandeh } & \text { inhā } & \text { ro } & \text { tozih midim beyn-e moteghayyerhā-ye } \\ \text { of course in } & \text { future these } & \text { OM } & \text { explain give between-Ez } & \text { variation-Ez } \\ \text { "That it is a problem for our situation- of course l'll explain them later- in varieties..." (MC) }\end{array}$

7 b)

$\begin{array}{llllllll}\text { un } & \text { khānandeh un } & \text { tafsirhaei ro } & \text { ke } & \text { mitune } & \text { az } & \text { jomle dāshteh } \\ \text { that } & \text { reader that } & \text { explanations OM } & \text { that } & \text { can } & \text { from } & \text { sentence have } \\ \text { bāshe } & \text { kāhesh bedeh } & \text { albatte dar } & \text { edāme } & \text { man } & \text { inā } & \text { ro } & \text { hatman } \\ \text { be } & \text { decrease give } & \text { of course in } & \text { continue } & \text { I } & \text { these } & \text { OM } & \text { certainly } \\ \text { tozih } & \text { midam yek } & \text { matn barā-ye } & \text { inke } & \text { shekl } & \text { begire } & & \\ \text { explain } & \text { give } & \text { one } & \text { text } \text { for-Ez } & \text { this } & \text { form } & \text { give } & \end{array}$

"Which decreases the explanations of that reader from the sentence- of course l'll explain them- for forming a text..." (FC)

In $7(a, b)$, personal asides allow candidates to address the audience directly by briefly interrupting the argument to offer a comment on what has been said. While asides express something of the speaker's personality and willingness to explicitly intervene to offer a view, they can also be seen as a key audience-oriented strategy. By turning to the audience in mid-flow, the speaker acknowledges and responds to an active audience, often to initiate a brief dialogue that is largely interpersonal (Hyland, 2005). As we can see, such comments often add more to the speaker-audience relationship than to the propositional development of the discourse $(7 a, b)$.

\subsection{Self-mentions}

Self-mentions seem to be the only subcategory which MCs use more than FCs (Table 2). The candidates show their professional identities by self-mentioning, as illustrated in $8(a, b)$.

8 a)

$\begin{array}{lllllll}\text { chārchub-e } & \text { tahghigh-emā } & \text { ma } & \text { az } & \text { se } & \text { nazariye tashkil shode } \\ \text { framework-Ez } & \text { research-Ez } & \text { we } & \text { from } & \text { three } & \text { theory form } & \text { become }\end{array}$

8 b)

"Our research framework has included three theories" (MC)

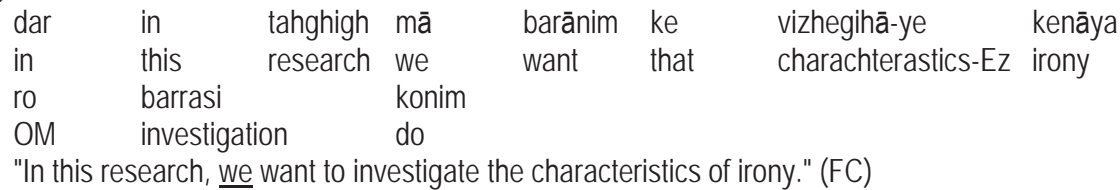

The self-mention "mā" in $8(a, b)$ reveals the speakers' persona, establish their credentials and present them as original contributors. Rowley-Jolivet and Carter-Thomas (2005) state that the frequent use of pronouns can be related to certain contextual constraints of the academic speech environment; secondly, speakers have to adapt to the high 
informational content of their talks in a live delivery (Hyland, 2005: 60). Moreover, since the complex nominal subject groups are both difficult to produce and understand in real time, initially placed subjects facilitate real time processing (Rowley-Jolivet and Carter-Thomas, 2005:60).

\section{Discussion}

As the quantitative analysis of the data reveals, there seems to be some gendered differences in the use of interactional metadiscourse markers. FCs use interactional metadiscourse markers more than MCs. The only subcategory which MCs use more than their female counterparts is self-mention. It shows that the professional identity of being constructed as researchers is more important for MCs. In contrast, FCs have used hedges more than MCs. By using hedges (contentmotivated and speaker-motivated), they try to avoid bare assertion in academic discourse, albeit not being an indication of uncertainty which is the characteristic of women talk in previous approaches (Ochs, 1992). There is almost no difference in the frequency of boosters by MCs and FCs. They tend to highlight the certainty they feel toward the proposition being asserted. A greater use of attitude markers and engagement markers by FCs also reveals that the interpersonal communication for them is more important in this community of practice. So, the quantitative analysis shows a difference in the use of interactional metadiscourse markers by MCs and FCs. However, the qualitative analysis helps the authors to identify more similarities than differences. In a sense, both groups have used the same strategies for content-motivated and speaker-motivated hedges, boosters, attitude markers, engagement markers and also selfmentions. Overall, in our data, gender does not affect the quality of the use of interactional metadiscourse markers.

\section{Conclusion}

This paper has analyzed the use of interactional metadiscourse in the defense seminars of Persian speakers in order to discern the similarities and differences of gendered linguistic behavior. The study is conducted both quantitatively and qualitatively to answer the research question: what similarities and differences can be found in the use of interactional metadiscourse by male and female candidates in the sessions of thesis defenses? The quantitative analysis shows that there is a significant difference between MCs and FCs in using the interactional metadiscourse markers. Nevertheless, both MCs and FCs are heavy users of self-mentions. A high frequency of employing this category by the both groups clearly establishes their credentials and highlights their professional identity. FCs tend to use attitude markers, boosters, engagement markers and hedges (content-motivated and speaker-motivated) more frequently than MCs which reveals that the interpersonal communication for them is more important in this community of practice. However, qualitatively, they use the same strategies for showing content-motivated and speaker-motivated hedges, boosters, attitude markers, engagement markers (by using the same audience pronouns and personal asides) and also self-mentions. It seems that the power of the genre (TD) and the interactional purposes strongly influence the speakers' performance; consequently, some similarities can be observed in their use of interactional metadiscourse markers.

Based on the results of this study, the claim of some Iranian researchers (such as Aghapour et al, 2009), describing the higher educational system in Iran as a male-gendered organization, cannot easily be accepted; the description of university as a male-gendered organization as it is stated for traditional university like many other old institutions (Acker, 1990; Caplan, 1994), does not seem to be so relevant for the present community of practice in Iran.

\section{References}

Abdi, R. (2009). Projecting cultural identity through metadiscourse marking; a comparison of Persian and English research articles. Journal of English Language Teaching and Learning 52, 1-15.

Abdollahzadeh, E. (2007). Writer's presence in Persian and English newspaper editorials. Paper presented at the international conference on Systemic Functional Linguistics in Odense, Denmark.

Acker, J. (1990). Hierarchies, jobs, bodies: a theory of gendered organizations. Gender \& Society 4 (2), 132-58.

Ädel, A. (2006). Metadiscourse in L1 and L2 English. Amsterdam: John Benjamins.

Aghapur, M. \& Pazargadi, M. \& Azadi Ahmadabadi, Gh. (2009). The evaluation of the coincidence of social situation of women professors in universities with ratifications of "Higher Council of Cultural Revolution". Pazhuheshe Zanan [Women Studies] 7(3), $5-26$.

Caplan, P. J. (1994). Lifting a ton of feathers. A woman's guide to surviving in the academic world. Toronto: University of Toronto Press.

Chafe, W. (1982). Integration and involvement in speaking, writing and oral literature. In D. Tannen (ed), Spoken and Written Language: Exploring Orality and Literacy (pp. 35-53). Norwood, NJ: Ablex.

Crismore, A. (1984). The rhetoric of textbooks: Metadiscourse. Journal of Curriculum Studies 16 (3), 279-296. 
Crismore, A. \& Markkanen, R. \& Steffensen, M. (1993). Metadiscourse in persuasive writing: A study of texts written by American and Finnish university students. Written Communication 10(1), 39-71.

Eckert, P. \& McConnell-Ginet, S. (1992). Think practically and look locally: language and gender as community-based practice. Annual Review of Anthropology 21, 461-90.

Hyland, K. (1996). Talking to the academy: Forms of hedging in science research articles. Written Communication 13 (2), $251-81$.

Hyland, K. (1998). Exploring corporate rhetoric: Metadiscourse in the CEO's letter. Journal of Business Communication 35(2), $224-45$.

Hyland, K. \& Tse, P. (2004). Metadiscourse in academic writing: a reappraisal. Applied Linguistics 25 (2), 156-77.

Hyland, K. (2005). Stance and engagement: a model of interaction in academic discourse. Discourse Studies 7(2), $173-192$.

Lakoff, R. (1975). Language and Woman's Place. New York: Harper and Rowe.

Mills, S. (2003). Gender and Politeness. Cambridge: Cambridge University Press.

Ochs, E. (1992). Indexing gender. In A. Duranti \& Ch. Goodwin (eds.), Rethinking Context: Language as an Interactive Phenomena (pp. 335-58). Cambridge: Cambridge University Press.

Rowley-Jolivet, E. \& Carter-Thomas, Sh. (2005). The rhetoric of conference presentation introductions: Context, argument and interaction. International Journal of Applied Linguistics 15(1), 45-70.

Simin, Sh. (2004). Metadiscourse Knowledge and Use in Iranian EFL Writing. Unpublished MA. Thesis, Isfahan University.

Talbot, M. (2010). Language and Gender. (2nd ed.). Cambridge: Polity Press.

Thompson, G. (2001). Interaction in academic writing: Learning to argue with the reader. Applied Linguistics 22(1), 58-78.

Vande Kopple, W. J. (1985). Some Exploratory Discourse on Metadiscourse. College Composition and Communication 26, 82-93. 